BUDGETING : Journal of Business, Management and Accounting

Volume 2, Nomor 1, Desember 2020

e-ISSN: 2715-2480

p-ISSN: 2715-1913

DOI : https://doi.org/10.31539/budgeting.v2i1.785

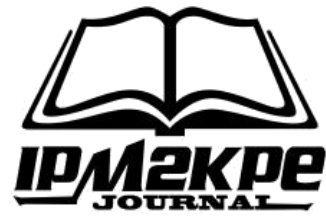

\title{
FENOMENA VIRAL MARKETING TERHADAP PEMBELIAN ULANG
}

\author{
Fatimah azzachra $^{1}$, Erry Sunarya $^{2}$, Faizal Mulya $^{3}$ \\ Universitas Muhammadiyah Sukabumi ${ }^{1,2,3}$ \\ Azzachra9763@gmail.com ${ }^{1}$
}

\begin{abstract}
ABSTRAK
Tujuan penelitian ini adalah untuk mengetahui pengaruh fenomena viral marketing terhadap pembelian ulang pada Holland Bakery Sukabumi. Metode penelitian yang digunakan pada penelitian ini adalah kuantitatif jenis nonprobability atau convenience sampling dengan jumlah responden sebanyak 81 orang. Teknik analisis yang digunakan yaitu teknik analisis regresi linear sederhana, uji validitas, uji reliabilitas, termasuk uji koefisien determinasi dan koefisien korelasi ganda. Analisis data yang digunakan pada penelitian ini adalah deskriptif dan asosiatif. Hasil penelitian menunjukkan bahwa uji koefisien determinasi menunjukkan nilai (Adjust $\mathrm{R}^{2}$ ) sebesar 0,512 dengan persentase viral marketing terhadap pembelian ulang adalah sebesar $51,2 \%$ sedangkan sisanya $0,488(48,8 \%)$ dipengaruhi oleh faktor-faktor yang lain diluar penelitian ini. Simpulan, viral marketing berpengaruh secara simultan terhadap pembelian ulang.
\end{abstract}

Kata Kunci: Fenomena, Pembelian Ulang, Viral Marketing

\begin{abstract}
The purpose of this study was to determine the effect of the viral marketing phenomenon on repurchasing at Holland Bakery Sukabumi. The research method used in this study is a quantitative type of nonprobability or convenience sampling with a total of 81 respondents. The analysis technique used is simple linear regression analysis technique, validity test, reliability test, including the coefficient of determination and multiple correlation coefficient. The data analysis used in this research is descriptive and associative. The results showed that the determination coefficient test showed a value (Adjust R2) of 0.512 with the percentage of viral marketing to repurchase of $51.2 \%$ while the remaining 0.488 (48.8\%) was influenced by other factors outside of this study. In conclusion, viral marketing has a simultaneous effect on repeat purchases.
\end{abstract}

Keywords: Phenomenon, Repurchase, Viral Marketing

\section{PENDAHULUAN}

Pertumbuhan ekonomi saat ini tidak terlepas dari pesatnya pertumbuhan bisnis. Hal ini tidak terlepas dari kemajuan teknologi yang terus berkembang di Indonesia. Pengembangan teknologi menghasilkan sebuah gagasan yang pada akhirnya mendorong pengembangan di dalam dunia bisnis salah satunya yaitu pemasaran (marketing) yang merupakan salah satu fokus utama dalam pengembangan teknologi yang diterapkan 
dalam dunia bisnis. Hal ini bertujuan untuk meningkatkan pemasaran bisnis yang lebih baik.

Saat ini perkembangan bisnis makanan mengalami kemajuan yang sangat pesat. Tidak hanya makanan tradisional tetapi juga makanan modern yang banyak dikonsumsi oleh masyarakat. Masyarakat berbondong-bondong mencari makanan yang serba cepat dan bukan termasuk makanan berat seperti nasi. Roti termasuk makanan ringan yang langsung bisa dipesan tanpa menunggu lama. Tidak bisa dipungkiri bahwa saat ini masyarakat lebih memilih roti untuk sarapan daripada nasi atau makan berat lainnya. Masyarakat saat ini perlu melakukan evaluasi dalam mengkonsumsi makanan untuk kebutuhan mereka terlebih dari segi kualitasnya.

Kesadaran dari perusahaan roti pada umumnya menjadi pertimbangan untuk terus bisa meningkatkan kualitas pelayanan dan kepuasan kepada para pelanggan yang akan memberikan timbal balik kepada perusahaan tersebut. Untuk meningkatkan pembelian ulang, maka perusahaan harus mengembangkan viral marketing agar konsumen dapat berkomunikasi untuk membeli produk. Hal ini dapat membantu kelancaran bisnis sebuah perusahaan seperti Holland Bakery.

Viral marketing yang baik dan dimiliki oleh konsumen bisa mendorong dirinya pada pembelian ulang untuk bisa membeli dengan begitu target penjualan produk Holland Bakery meningkat. Viral marketing yang baik dan dimiliki oleh konsumen bisa mendorong dirinya pada pembelian ulang untuk bisa membeli dengan begitu target penjualan produk Holland Bakery meningkat atau tercapai. Holland Bakery merupakan salah satu perusahaan pelopor untuk usaha bakery di Indonesia dengan sistem yang digunakan yaitu membuat produk yang berkualitas sehingga mampu memuaskan konsumen puas.

\section{KAJIAN TEORI}

\section{Viral Marketing}

Viral marketing merupakan suatu teknik pemasaran yang dirancang seperti virus berjangkit dari satu orang ke orang lainnya secara cepat dan luas melalui proses komunikasi secara terus menerus. Viral marketing memiliki hubungan dengan menciptakan sebuah e-mail atau cara pemasaran yang bisa membuatnya lebih viral. Hal ini dapat diartikan bahwa seorang konsumen yang puas akan suatu produk maka mereka 
bersedia atau mau menyebarkan dan menyampaikan kepada teman-teman mereka terhadap suatu produk yang akan dibeli.

Menurut Kotler \& Keller (2009) viral marketing adalah penyampaian dari mulut ke mulut versi internet, yang memiliki hubungan dengan menciptakan sebuah e-mail atau cara pemasaran yang sangat menular sehingga konsumen atau pelanggan bersedia atau mau untuk menyebarkan dan menyampaikannya kepada teman-teman mereka. Selanjutnya menurut Arifin (2003) viral marketing adalah suatu program yang dirancang seperti virus berjangkit dari satu orang ke orang lain secara cepat dan luas.

\section{Pembelian Ulang}

Pembelian ulang merupakan suatu keputusan konsumen juga suatu perilaku konsumen untuk melakukan pembelian akan suatu produk lebih dari satu kali. Konsumen yang puas akan suatu produk yang dihasilkan maka pembelian tersebut diputuskan oleh pelanggan ketika konsumen puas akan suatu produk tanpa menyertakan aspek kesukaan didalamnya. Kepuasan konsumen merupakan faktor yang sangat penting dalam membentuk perilaku pembelian ulang pada pembelanjaan suatu produk (Park et al., 2010).

Pembelian ulang merupakan salah satu perilaku setelah pembelian yang sebelumnya didasari dengan kepuasan. Jika pelanggan puas untuk selanjutnya dia akan memperlihatkan peluang membeli yang lebih tinggi dalam kesempatan berikutnya. Menurut Kotler \& Keller (2009) pembelian ulang adalah aktivitas dimana konsumen merasa puas akan suatu produk yang sesuai antara ekspetasi dengan performa yang diharapkan sehingga menciptakan suatu kepuasan yang mendorong terciptanya pembelian ulang atas produk atau merek yang sama dikemudian hari dan akan menceritakan mengenai hal yang baik atas merek tersebut.

\section{METODE PENELITIAN}

Lokasi yang dijadikan tempat penelitian adalah Holland Bakery Sukabumi di Jalan Jend. Sudirman no.79, Kota Sukabumi, Jawa Barat, Indonesia. Populasi terdiri atas objek atau subjek. Menurut Sugiyono (2010) populasi adalah wilayah generalisasi yang terdiri atas objek atau subjek yang mempunyai kualitas dan karakteristik tertentu yang ditetapkan oleh peneliti untuk dipelajari dan kemudian ditarik kesimpulannya. 
Populasi dalam penelitian ini adalah calon pembeli Holland Bakery dimana populasi ini mencakup semua orang yang pernah membeli produk Holland Bakery.

Metode pengumpulan data pada penelitian ini yaitu nonprobability sampling yaitu dengan menggunakan convenience sampling untuk mendapatkan atau mengumpulkan data dengan tujuan dan kegunaan tertentu secara ilmiah. Teknik ini dapat mempermudah dan pengambilan sampel dilakukan secara kebetulan namun didasari dengan ketentuan untuk memilih konsumen. Sampel yang digunakan pada penelitian ini sebanyak 81 orang responden. Penelitian ini menggunakan uji validitas dengan rumus product moment dan uji reliabilitas dengan rumus crobanch's alpha angket yang disebar menggunakan skala likert dengan pernyataan positif.

\section{HASIL PENELITIAN}

Berikut merupakan hasil pengamatan peneliti pada Holland Bakery Sukabumi melalui prakuesioner yang dibagikan kepada 10 responden.

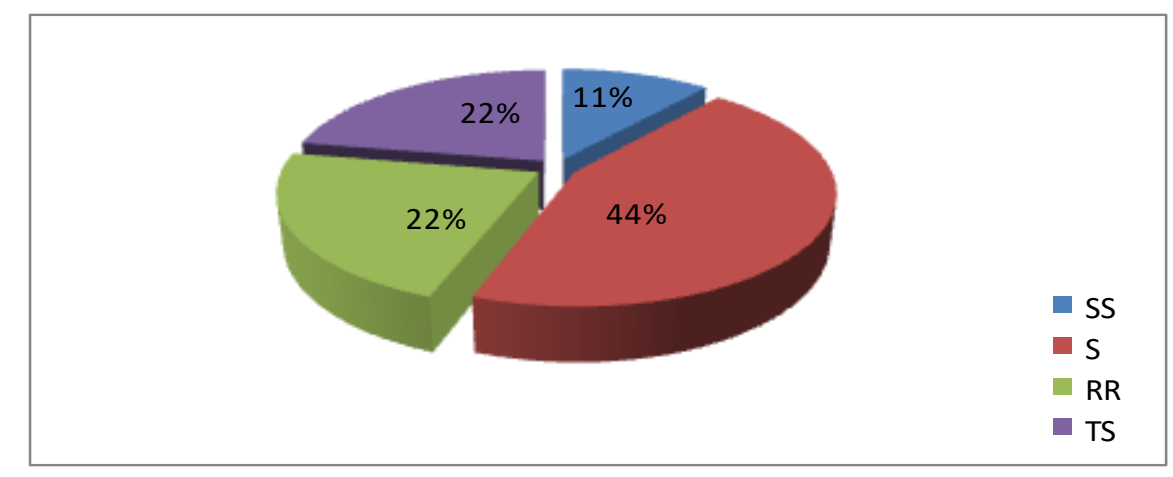

Gambar 2. Hasil Prakuesioner Pembelian Ulang pada Holland Bakery Sukabumi

Berdasarkan gambar 2, terlihat adanya permasalahan pada Holland Bakery Sukabumi mengenai pembelian ulang dengan persentase yang signifikan yakni sebesar 44\%. Viral marketing dapat berdampak negatif pada perusahaan yang akan mempengaruhi pembelian ulang dalam pencapaian tujuan perusahaan tersebut. Viral marketing di dalam perusahaan Holland Bakery Sukabumi dapat diakibatkan oleh pemasaran yang tidak viral sehingga konsumen tidak mampu menentukan pilihan utama pada produk Holland Bakery. Maka dari itu, secara garis besar hasil prakuisoner menunjukkan bahwa viral marketing sangat mempengaruhi pembelian ulang. Banyak konsumen yang dapat menentukan pilihan utama pada produk Holland Bakery. 


\section{Hasil Analisis Regresi Linear Sederhana}

Regresi linier sederhana sangat bermanfaat untuk meneliti pengaruh variabel yang berkorelasi dengan variabel yang diuji.

Tabel 1.

Hasil Uji Linier Sederhana

\begin{tabular}{|c|c|c|c|c|c|c|}
\hline \multicolumn{7}{|c|}{ Coefficients $^{\mathrm{a}}$} \\
\hline \multirow{2}{*}{\multicolumn{2}{|c|}{ Model }} & \multicolumn{2}{|c|}{$\begin{array}{l}\text { Unstandardized } \\
\text { Coefficients }\end{array}$} & \multirow{2}{*}{$\begin{array}{c}\begin{array}{c}\text { Standardized } \\
\text { Coefficients }\end{array} \\
\text { Beta }\end{array}$} & \multirow[t]{2}{*}{$\mathrm{T}$} & \multirow[t]{2}{*}{ Sig. } \\
\hline & & $\mathrm{B}$ & Std. Error & & & \\
\hline \multirow[t]{2}{*}{1} & (Constant) & 1,413 & 1,531 & & 0,923 & 0,359 \\
\hline & Viral Marketing & 1,141 & 0,124 & 0,720 & 9,220 & 0,000 \\
\hline
\end{tabular}

a. Dependent variable: Pembelian_ulang

(Sumber data primer (kuesioner), 2019)

Berdasarkan tabel diatas, maka dapat diketahui nilai dari persamaan regresi linear sederhana sebagai berikut: $\mathrm{a}=1.413 ; \mathrm{b}_{1}=1.141$. Selanjutnya didapatkan persamaan regresi linear sederhana untuk variabel viral marketing: $\mathrm{Y}=1.413+1.141$.

\section{Hasil Koefisien Determinasi}

Tabel 2.

Model Summary

\begin{tabular}{ccccc}
\hline \multicolumn{5}{c}{ Model Summary } \\
\hline Model & R & R Square & Adjusted $\mathbf{R}$ Square & Std. Error of the Estimate \\
\hline 1 &, $720^{\mathrm{a}}$ &, 518 &, 512 & 1,490 \\
\hline \multicolumn{5}{c}{ a. Predictors: (Constant), Viral_Marketing } \\
\hline
\end{tabular}

(Sumber data primer (kuesioner), 2019)

Berdasarkan tabel 2, diketahui bahwa korelasi variabel viral marketing terhadap pembelian ulang sebesar 0,512 (dilihat dari nilai $\mathrm{R}$ pada tabel diatas). Hal ini berarti 51,2 variasi viral marketing dapat dijelaskan dari variabel independen. Sedangkan pembelian ulang sisanya $48,8 \%(100 \%-51,2 \%=48 \%)$ dari faktor yang tidak diteliti.

\section{Koefisien Korelasi Sederhana (R)}

Tabel 3.

Hasil Koefisien Korelasi

\begin{tabular}{ccccc}
\hline \multicolumn{5}{c}{ Model Summary } \\
\hline Model & R & R Square & Adjusted R Square & Std. Error of the Estimate \\
\hline 1 & $0,720^{\text {a }}$ & 0,518 & 0,512 & 1,490 \\
\hline \multicolumn{5}{c}{ a. Predictors: (Constant), Viral_Marketing } \\
\hline
\end{tabular}

(Sumber data primer (kuesioner), 2019) 
Berdasarkan data tabel 3, diperoleh angka $\mathrm{R}$ sebesar 0,720 berada pada kategori kuat. Hal ini menunjukan bahwa terjadi hubungan yang sedang antara viral marketing terhadap pembelian ulang.

\section{Uji Signifikan Secara Simultan (Uji F)}

Tabel 4.

Hasil Uji F

\begin{tabular}{ccccccc}
\hline \multicolumn{7}{c}{ ANOVA $^{\text {a }}$} \\
\hline \multirow{3}{*}{1} & Model & Sum of Squares & df & Mean Square & F & Sig. \\
\hline \multirow{3}{*}{1} & Regression & 188,663 & 1 & 188,663 & 85,004 &, $000^{\text {b }}$ \\
\cline { 2 - 7 } & Residual & 175,337 & 79 & 2,219 & & \\
\cline { 2 - 6 } & Total & 364,000 & 80 & \\
\hline \multicolumn{6}{c}{ a. Dependent Variable: Pembelian_Ulang } \\
\hline
\end{tabular}

(Sumber data pengolahan, 2019)

Data tabel 4 menjelaskan bahwa hasil uji $\mathrm{F}$ variabel viral marketing terhadap pembelian ulang adalah sebesar 85,004 dapat diperoleh dari nilai sig. $0,000<0,05$, nilai $\mathrm{F}_{\text {hitung }} 85,004>\mathrm{F}_{\text {tabel }} 3.16$ artinya bahwa viral marketing berpengaruh secara simultan terhadap pembelian ulang.

\section{PEMBAHASAN}

Berdasarkan hasil hitungan penelitian analisi regressi sederhana. Nilai koefisien determinasi $\left(\mathrm{R}^{2}\right)$ hasil dari variabel viral marketing $(\mathrm{X})$ mempengaruhi sebesar 51,2\% $(0,512)$ terhadap pembelian ulang (Y). Sisanya 48,8\% $(0,488)$ dipengaruhi oleh faktor lain diluar penelitian ini. Dikarenakan dampak dari viral marketing berpengaruh dalam pembelian ulang. Dengan demikian dapat diketahui bahwa viral marketing (X) merupakan faktor yang berpengaruh siginifikan terhadap pembelian ulang (Y) pada Holland Bakery Sukabumi secara simultan.

Holland Bakery merupakan salah satu perusahaan pelopor untuk usaha bakery di Indonesia. Mulai berdiri dari tahun 1978 hingga sekarang, dibawah PT. Mustika Citra Rasa dan beberapa perusahaan lainnya yang berafiliasi pada cabang-cabang diseluruh luar jabodatebek dan bandung. Visi yang dimiliki Holland Bakery yaitu menjadikan produknya sebagai salah satu pilihan makanan pokok masyarakat Indonesia, sehat dan 
bergizi, mudah dijangkau oleh seluruh masyarakat semua golongan serta tentunya dibuat oleh tangan-tangan ahli, putra-putri terbaik Indonesia.

Segenap upaya terus dilakukan Holland Bakery dengan selalu menjaga bahan baku tetap berkualitas tinggi, sistem operasional yang terstandarisasi, keamanan pangan dan terus mengembangkan inovasi dari produk roti, cake dan tart baik dari segi rasa, maupun design dan bentuknya serta cita rasa yang terus mengikuti perkembangan trend terkini. Kualitas adalah hal yang paling utama, pengelolaan produksi produk Holland Bakery dilakukan dengan pengendalian kualitas kontrol produksi yang ketat, mulai dari pemilihan bahan baku, pengelolaan bahan menjadi produk siap saji hingga proses pasca produksi. Tidak hanya sampai disitu, demi menjaga dampak lingkungan sekitar, Holland Bakery juga membangun instalasi pembuangan limbah produksi dan mengolahnya hingga aman untuk lingkungan sekitarnya.

Dalam upaya Holland Bakery menjaga kualitas produk agar tetap fresh, berkualitas baik dan selalu baru, Holland Bakery pun menstandarisasikan sistem suplai produk yang sangat ketat jadwalnya dengan melakukan pendistribusian produk dalam satu hari minimal 3 (tiga) kali jadwal pengiriman.

Secara umum, dengan adanya viral marketing seharusnya dapat memberikan dampak yang positif yang mendukung perluasan jangkauan pemasaran produk kepada konsumen. Hal ini sejalan dengan penelitian yang dilakukan oleh Wiludjeng \& Nurlela (2013) yang menemukan bahwa viral marketing berpengaruh secara signifikan pada keputusan beli konsumen sehingga produsen disarankan untuk melaksanakan viral marketing untuk ditingkatkan, mengingat pelaksanaan viral marketing dapat memberikan informasi lebih luas, cepat dan tepat kepada masyarakat.

Berdasarkan hasil penelitian Siyamtinah \& Hendar (2015) nilai manfaat lebih dominan dalam membetuk kepuasan dan kepercayaan konsumen sehingga pada akhirnya akan mempengaruhi pembelian ulang.

\section{SIMPULAN}

Berdasarkan hasil analisis dan pembahasan mengenai pengaruh viral marketing terhadap pembelian ulang pada Holland Bakery menunjukkan bahwa hasil garis kontinum, penilaiannya masih rendah yaitu responden paling banyak memberikan nilai 3 yang artinya viral marketing masih dinilai belum baik. Responden menanggapi bahwa 
mereka masih belum memahami informasi produk dengan baik, begitupun pada saat menyampaikan informasi tentang produk. Hal ini bermakna bahwa produk yang dihasilkan oleh Holland Bakery masih belum menarik di mata konsumen-konsumen tersebut. Sedangkan responden yang lainnya sudah menilai baik karena jawaban yang paling banyak memberikan nilai 4 bahwa mereka memahami informasi produk dengan baik dan juga mampu menyampaikan informasi produk dengan baik dan produk yang dihasilkan oleh Holland Bakery menarik di mata responden.

Penilaian rendah juga diperoleh pada respon mengenai pembelian ulang dimana responden memberikan nilai 3 yang artinya masih dinilai belum baik. Responden menanggapi bahwa mereka tidak sering membeli produk karena mereka belum mampu mencari informasi produk dengan baik juga mereka tidak dapat merekomendasikan produk sehingga tidak dapat menentukan pilihan utama produk yang ada di Holland Bakery. Sedangkan responden yang lainnya sudah menilai baik karena jawaban yang paling banyak memberikan nilai 4 bahwa mereka mampu mencari informasi produk dengan baik juga dapat merekomendasikan produk sehingga dapat menentukan pilihan utama produk yang ada di Holland Bakery.

Berdasarkan hasil analisis viral marketing terhadap pembelian ulang bahwa $51,2 \%$ sisanya $48,8 \%$ dipengaruhi oleh faktor lainnya, sedangkan berdasarkan uji koefisien korelasi sederhana dapat dilihat dari nilai $\mathrm{R}$ sebesar 0,715 yang menunjukan bahwa terjadi kekuatan hubungan antara viral marketing terhadap pembelian ulang. 


\section{DAFTAR PUSTAKA}

Arifin, A. (2003). FAQ about Viral Marketing. Yogyakarta: Andi Offset

Kotler, P., \& Keller, K. (2009). Manajemen Pemasaran, Jilid I Edisi ke 13. Jakarta: Erlangga

Park, I., Bhatnagar, A., \& Rao, H. R. (2010). Assurance Seals, On-Line Customer Satisfaction, and Repurchase Intention. International Journal of Electronic Commerce, 14(3): 11-34

Siyamtinah, S., \& Hendar, H. (2015). Meningkatkan Pembelian Ulang Melalui Kepercayaan dan Kepuasan pada Pembelanjaan Online. $2^{\text {nd }}$ Conference in Business, Accounting and Management, 2(1), 435-448

Sugiyono, S. (2010). Metode Penelitian Pendidikan Pendekatan Kuantitatif, Kualitatif dan $R \& D$. Bandung: Alfabeta

Wiludjeng, S., \& Nurlela, T. S. (2013). Pengaruh Viral Marketing terhadap Keputusan Pembelian pada PT. X. Proceeding Seminar Nasional dan Call for Papers SANCALL. Surakarta 